\title{
Store Brand Purchase in the Italian Market
}

\author{
Guido Cristini ${ }^{1}$ \& Cristina Zerbini ${ }^{1}$ \\ ${ }^{1}$ Department of Economics and Management, University of Parma, Italy \\ Correspondence: Cristina Zerbini, Department of Economics and Management, University of Parma, Italy. \\ E-mail: cristina.zerbini@unipr.it
}

Received: February 4, 2018

doi:10.5539/ijbm.v13n7p126
Accepted: May 3, 2018

Online Published: June 15, 2018

URL: https://doi.org/10.5539/ijbm.v13n7p126

\begin{abstract}
The paper analyzes the degree of importance of Store Brand purchase determinants for the consumer. In particular, the research focuses on two specific shopper segments (hypermarket shopper and supermarket shopper) in order to evaluate the existence of any significant differences between their product evaluations. Telephone interviews, based on a structured questionnaire, were conducted with a sample of consumers responsible for family purchases and buyers of Store Brand products. For the majority of the purchasing determinants investigated, the results show a significant difference in opinion between those buying Store Brand products in hypermarkets and those in supermarkets. The difference found between shopper profiles has significant managerial implications that could be useful for determining Store Brand management policies. This paper also contributes to the academic debate on the role of Store Brand in the retail market.
\end{abstract}

Keywords: store brand, purchase determinants, shopper behavior, distribution format

\section{Introduction}

As known, in most advanced countries, the continuous development of Store Brand (SB) for the consumer market is attributable to factors of both supply and demand (Sethuraman \& Gielens, 2014) ${ }^{1}$.

With regard to variables related to consumer behavior, it seems evident that almost all families who choose to buy a SB product do not only consider the price, but also other elements which have grown in importance over time, such as product quality and safety.

The result is that over the last few years, the SB has contributed, albeit in different ways depending on the country (Esbjerg, Grunert, Bech-Larsen, Juhl, \& Brunsø, 2005), to strengthening retailers' reputations. In particular, those retailers who set ambitious goals to bolster their own SB by continually improving its distinguishing characteristics.

With this in mind, the present paper intends to demonstrate that the success of SBs in the Italian market not only depends on the price differential between the SB and its corresponding industrial brand, but also on other factors that have become increasingly important over time to the final consumer. These include the level of quality (intrinsic and perceived), sustainability, the guarantee of safety through a certification system, the assortment variety, ethics and a propensity for innovation.

Specifically, the main objective of the paper is to understand which of the aforementioned attributes appear to be most important in a purchase decision, assuming that the way the consumers shop (in terms store format) has an impact on their expectations and therefore conditioning their evaluation.

To examine this topic more closely, the study develops a field research aimed at discover the Italian consumers' perceptions of the SB, to understand which of product's differentiating factors had the greatest impact on the final decision to buy. In this context, the consumers were analyzed according to the store format in which they habitually shopped. More specifically, a comparative study was made between hypermarket and supermarket shoppers, assuming that way of they spend, their shopping frequency and sensitivity to price differs between store formats.

In fact, the assortment choices, the price policies pursued, as well as the organization of services offered within the two formats (even within the same chain) can impact consumers' expectations and perceptions. Therefore, the insights gained from the present study will be useful to management looking to increase SB penetration in a given store format and, as a result, improving final consumer loyalty. 
The remainder of the paper is organized as follows. The next section reviews the relevant SB development retailing literature and the factors that can consolidate its reputation. The subsequent sections propose the research questions, while the "Method" section presents the survey conducted. The last paragraphs present numerical results and discussion, highlighting theoretical and managerial implications.

\section{Literature Review}

The topics of branding and of the characteristics which contribute to differentiate the identity and value of the brand to final consumer are quite widely covered in marketing literature, given how important the issue is to the value creation strategies implemented by individual companies. In this conceptual context, this paper aims to analyze those scientific contributions dealing with a brand's claim within the distribution setting, and whose objective, therefore, is to investigate how distribution groups have managed to grow their total brand equity by leveraging their SB and increasing its market penetration.

The consumers' appreciation of SBs has increased over time as a result of ongoing work by the major international distribution groups to identify and develop their brands' distinguishing characteristics. In fact, the literature demonstrates how the characteristics that are currently used to identify a SB are the result of the implementation of specific strategies aimed at increasing the brand's overall positioning.

First and foremost, the SB has been known for offering a price advantage or rather, the difference generally found between the distributor's offer and that of the equivalent leading industrial brand. The differential for each product category is measured by research institutes whose role is to record the modern distribution channels' sales information at an individual country level. With reference to the standard price range in Italy, the average price index (set equal to 100) indicates that SBs are positioned at $87^{2}$.

Obviously, average price distance between the leading brand and the SB can differ depending on to the country, the concentration of industrial markets found within a category, the share held by the SB and the type of distribution format considered, making it difficult to identify a single SB price advantage threshold valid for all contexts. For this reason, with respect to industrial brands, the price distance indicator assumes different values according to the variables considered (category type, channel type, analyzed SB, etc.). As a consequence, the perception of a SB's price advantage differs not only according to the policies adopted by the retailer, but also to the reputational value built over time. The more a SB is considered a real "brand" by the consumer, the higher its positioning can be, or rather, the closer it is to corresponding brand leader.

Yet, the pioneering contributions of Hoch and Banerji (1993), Dhar and Hoch (1997) later studies, and the more recent works of Rubio and Yagüe (2009), Lamey, Deleersnyder, Steenkamp and Dekimpe (2012) and Sethuraman and Gielens (2014), all demonstrate that SB price, despite remaining a carefully-considered factors, is no longer the only element evaluated by the consumer making a purchase.

However, in regard to consumer products, it's evident that price advantage still appears to be a key factor in attracting final demand. Except for rare exceptions, a SB is offered at a lower price than the corresponding leading brand, and retailers highlight this promotional policy in their communication campaigns.

Another important factor influencing the perceived value of the SB is quality. Retailing literature has shown that quality, together with a price advantage, is essential to the consumer and to the retailer. Bettman (1974), Klein and Leffler (1981) and Baltas (1997) demonstrate how over the years, product quality assurance, as guaranteed by the SB, represents a major part of the brand's claim. Quality has also been studied by Hoch and Banerjy (1993), who state that the quality-price ratio is central to consumer's evaluation. A price advantage alone is not enough to impress the consumer, the perceived quality of the SB product must also be high, thus making the brand truly comparable to its corresponding industrial product. Moreover, in their work, the authors cite research conducted by Gallup in 1990 (published in the Progressive Grocery) on consumer behavior and the evaluation of perceived quality. The results show that $85 \%$ of consumers interviewed consider quality to be the defining factor behind their SB purchase.

It is also useful to mention the studies of Garretson, Fisher and Burton (2002), Veloutsou, Gioulistanis and Moutinho (2004) and Erdem and Chang (2012) in which consumer preference survey results from different countries confirm that product quality is central to the consumer's decision-making process. Furthermore, Walsh and Mitchell (2010) highlight how the perception of product quality may differ based on a consumer's degree of familiarity with a type of brand as well as in relation to the role assigned to the category by the shopper. Another example of how important quality has become is the addition of premium SB products to the Italian retailers' assortment; products made according to local tradition or specific to a certain territory (i.e., PDO or PGI products or made using local recipes). This growing phenomenon, not confined only to Italy, contributes in a 
positive manner to the SB's perceived quality. In fact, these products are known for having an intrinsically higher level of quality.

A third determinant which can make a SB stand out is its promise of food safety: the processes retailer undertakes to ensure that each product conforms to the dictate of consumer health protection. The globalization of the markets, which favors an increasing delocalization of production, increases the relevance of SB safety certifications. Studies from the Nineties (e.g., Caswell \& Mojduszka, 1996; Verbeke \& Viaene, 1999; Trijp, Steenkamp, \& Candel, 1997) explore the consumer experience in regards to the quality assurance processes put into place by distribution chains to support their products. Indeed, the first differentiation policies to be implemented and promoted by leading industrial brands can be traced back to those years. The objective was to let consumers know about the effort being made to set up control processes along the supply chains through a series of agreements made with the supplying companies. The product, or process, certification system is a key condition behind a purchase decision for those shopper segments sensitive to food safety. Since a customer generally knows less about a SB than the leading industrial brand, the process of ensuring a product's high quality level through the involvement of co-packers helps to generate a reduction in the level of risk perceived by the demand. Therefore, it is not surprising that part of a SB's job in regards to guaranteeing product safety has to do with labeling, or rather, the communication policies used for product packaging since it is one of the key ways used to inform consumers about a product's distinguishing characteristics.

Sustainability is another factor which is becoming increasingly important to the debate on purchasing decisions and brand selection. In fact, in the most well-developed countries, consumers require that the retailers to whom they are most loyal adopts policies that support sustainability and therefore, that their SB products are conform to this dictate as well.

This translates into an individual retailer assuming a proactive role to defend the environment by adopting policies which aim to reduce or eliminate any negative side-effects derived from their actions for the community. An example can be found in the field of logistics: from the rethinking of primary and secondary SB product packaging in order to reduce overall packaging dimensions or to re-use materials, to the selection of raw materials used in the products preparation, to making sure that the upstream supply chain is environmentally friendly. The retailers' growing attention to sustainability explains the increased attention paid to the selection of co-packer companies who must also offer environmentally friendly processes and products. Other examples include the methods pursued in the fish supply process at global level and the choices made regarding the tree reproduction cycle for the purpose of selecting cellulose for paper-based products. Proof of the sustainability's growing importance can see in the retailers' adhesion to medium-to-long term strategies in which they will prove their commitment to defending the environment. In this framework, each retailer must let the consumer know about the policies they have implemented aimed at reducing the negative effects on the environment as a result of their economic activity (for example, the reduction of energy consumption at the points of sale, package recovery systems, the creation of social projects aimed at recovering expiring products).

Retailing literature about sustainability appears to be less extensive and exhaustive than it is for the aforementioned factors (price advantage and quality), demonstrating how the issue, in relation to SBs, is still rather limited. The literature that does exist on the subject tends to focus on leading industrial brands, for whom sustainability can be a value-creating factor within the implemented marketing strategies. Among the studies supporting this perspective, Gupta and Kumar (2013) highlight how a brand can be the driver of an environmentally friendly culture, thus improving the perceived positioning of the company. In the study cited, there are several lines of thought which support a vision of $\mathrm{CSR}^{3}$ as a policy that needs to implemented particularly by those companies operating in global markets. When analyzing the Social Report of various international groups, it becomes clear how environmental and social sustainability play an increasing role in the strategies of a growing number of retail companies ${ }^{4}$.

SB retailing literature also covers the highly-debated subject of innovation. In several studies, it stated that the goal of a distributor is not only to apply innovative strategies to their assortment offer, but rather, to that of their services (Lugli, 2009). In fact, product innovation is a major goal of leading manufacturers who wish to create a lasting competitive advantage over their competitors (the follower and the local brands). For example, Doyle and Bridgewater (1998), Hardaker (1998) and Brenner (1994) have shown that innovation represents the main value driver for many industrial companies who have been able to maintain distinctive leadership over time. In addition, some studies have shown how innovation is the tool most frequently used by industrial brands to counter SB attacks (Verhoef, Nijssen, \& Sloot, 2002). In fact, Kumar and Steenkamp (2007) report that the degree of SB penetration is greater in categories that are characterized by a more modest level of innovation. Conn (2005) cited how distributors began to implement product innovation strategies for their own products, 
albeit only in certain categories, aimed at limiting their dependence on leading producers.

Although the majority of studies argue that the propensity for product and process innovation stems from branded industrial companies (Chimhundu, Hamlin, \& Mcneill, 2010), it is also true that major European distribution chains have updated their SB products portfolio by creating a distinctive and innovative offer thanks to the increasing integration of the $\mathrm{R} \& \mathrm{D}$ and marketing functions. These strategies have been implemented by identifying and selecting co-packers who are able to guarantee a certain degree of product innovation. Often this process leads to the definition of the offer, frequently in the key categories in order to attract consumers ${ }^{5}$, using products made by those co-packers who are able to provide the retailer with a totally distinctive product. An example can be found by looking at the premium SB offer: one of its critical success factors lies in a company's choice of supplier, one able to create products with characteristics (place and production method, raw materials used, type of recipe, etc.) differentiating them even from those of leading industrial brands. In the Italian market, this strategy mainly applies to premium SB segments, those identifiable with local tradition or the use of specific local recipe; where one of the consumer's criteria of choice might be the archetype of a "artisanal" or niche product, not found in the national offer (Cristini, 2012).

Could variety (of formats, products, variations, tastes, etc.) be an additional deciding factor behind the success of a SB? It certainly can, particularly in reference to those categories where consumers want to be able to choose from a vast assortment. In fact, this desire to choose between various alternatives can be satisfied, therefore satisfying one of the most essential needs linked to curiosity and experimentation as well.

Over the years, SBs have essentially responded in two ways to the ongoing process of demand segmentation caused by new consumer behavior, such as this desire to choose from different products and brands within the same category. The first response has been to expand the number of available SB products. This strategy can be implemented by inserting new products within traditional segments, or by proposing new consumption segments (or sub-segments) able to respond to the previously unmet requests of the demand.

The second approach has been to develop specific types of SBs to respond to different needs, applying price-differentiation positioning strategies in consideration of both the supply and demand. Among those studies focusing on the process of assortment expansion through the proliferation of various types of SBs, Geyskens, Gielens and Gijsbrechts (2010) and Ter Braak, Geyskens and Dekimpe (2014) should be mentioned. Their reports highlight which factors have the greatest influence over consumer choice, particularly in regard to the premium segment. The results of recent research ${ }^{6}$ confirm that major retailers are interested in developing these assortment expansion policies around the SB rather than the industrial brand (national or local).

One additional factor to consider is the increasing attention to ethics. Various scholars (e.g., Bodur, Tofighi, \& Grohmann, 2016) have approached this topic, bringing two particularly relevant and worthy aspects to light regarding modern distribution systems. Firstly, that being perceived as "ethical" is more useful to a SB than a national brand, since the latter is generally already more well-known to the shopper. Secondly, with reference to brands in general, ethics is not a factor in itself able to positively influencing the purchase intention. In fact, Lin and Chang (2012) pointed out that this attribute is not always seen as "positive", since it ca be associated with a potential cost to the retailer in ensuring that the production (or transformative) processes along the supply chain are "ethical". Furthermore, Gupta and Sen (2013) found that a great number of consumers associate ethical products with a possible lack innovation or lower quality. Authors argue how during brand enhancement processes there can be a sort of trade-off between ethical commitment (and the allocated resources) and an investment in quality, innovation and service.

However, companies do understand the importance of maintaining ethical values and must meet certain prerequisites recognized and certified on a national and international level. For example, they need to maintain effective health and safety regulations in the workplace, prohibit any type of discrimination, defend the right to collective bargaining, respect a predefined weekly work schedule and refuse to work with co-packers who partake in unethical behavior like exploiting child labor.

In regards to SBs, the real challenge faced by retailers is to be able to manage their suppliers through the entire process down the supply chain. In fact, Bodur et al. (2016) and Egan-Wyer, Muhr, Pfeiffer and Svensson (2014) demonstrated how this ethical challenge has become increasingly important to a large segment of the demand and how it is also becoming a true key factor for the consumer when choosing a brand. Indeed, it has become mandatory for a SB to have ethical characteristic, since without them, a distributor would be hard-pressed to guarantee itself those fundamental reputational values to increase consumer loyalty. 


\section{Research Questions}

In light of the literature analyzed, Figure 1 provides a summary of the distinguishing factors which characterize a SB. The pyramid indicates the degree of diffusion of these factors in terms of the Italian SB retailer. The most well-established and longstanding distinguishing factors can be found at the base of the pyramid. Moving up the ladder, one finds the newer and less well-established factors; those still part of a first phase of communication to and appreciation by the consumer. Indeed, some of the factors placed at the top of the pyramid (such as sustainability or innovation) are not yet found in several SBs offered by Italian retailers.

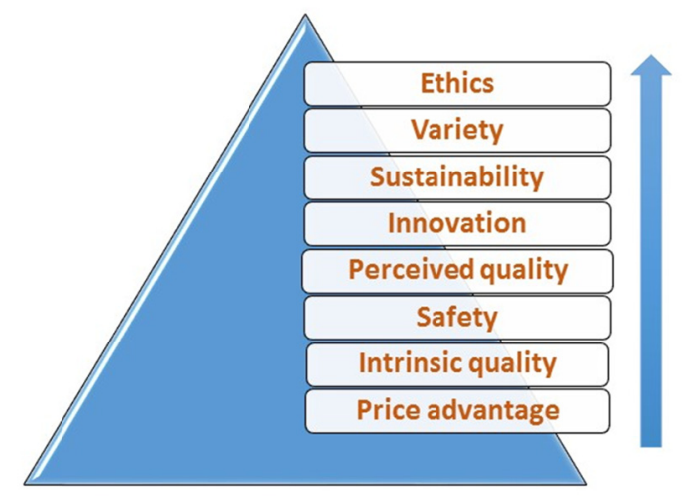

Figure 1. SB purchase determinants

Therefore, two main considerations regarding consumer behavior can be put forth.

The first relates to the relevance and congruence of aforementioned attributes (Figure 1) with reference to Italian SB. As known, Italian retailers show a delay in the modernization and concentration process. As a result, it detects a delay in overall size development and in the ability to implement advanced strategies for SB development compared to what has been achieved by some excellent distribution groups present in advanced distribution systems (with reference to the European market: UK, Germany, France, Holland, Spain, etc.).

In particular, it is important to understand whether the distinguishing factors that characterize the top retailers' SBs are aligned with the value system and expectations of the Italian consumers, given the overall economic situation and available purchasing power.

It is also important to verify whether purchasing behavior can influence this assessment, and whether the choice of a particular channel can determine different expectations and perceptions of the SB, not only in terms of the whole brand, but also in regard to each individual factor. This makes it possible to reveal whether the reasons that push the hypermarket consumer to purchase SB product are the same, or different, then those of a neighborhood supermarket shopper. In fact, expectations, priorities and perceptions of the same SB can differ depending on the type distribution format visited.

The present work aims to analyze the potential existence of differences in the SB evaluation between two groups of shoppers who, although loyal to the same retailer, shop in two different types of distribution formats. Therefore, the evaluations made by those shoppers who primarily buy a SB in hypermarkets is herein compared and analyzed to those who prefer the supermarket.

This study intends to provide the answers to two different research questions. The first one examines the existence of a discrepancy between the SB evaluations made by shoppers due to the distribution format where they generally make their purchases, which, for the purpose of this study, are hypermarkets or supermarkets. The second question examines the confirmation of a discrepancy in the evaluation between the two groups at the level of a single variable (price advantage, quality, sustainability, ethics, etc.). In short, the two research questions can be summarized as follows:

RQ1: Is there a significant difference between the SB evaluation made by a shopper who normally frequents a hypermarket and one who shops at a supermarket?

RQ2: Which of the distinguishing characteristics of a SB receive different evaluations: from the two shopper groups analyzed? 


\section{Method}

The present research analyzes the SB products found in the supermarket and hypermarket assortment. The universe investigated is made up of consumers, resident in Italy, responsible for their family's purchases and who buy SB products in one of these two distribution formats.

In order to respond to the research questions postulated, a survey, based on a structured questionnaire, was designed and implemented through computerized telephone interviews (CATI methodology). The survey took place in October 2016.

Of the 1,519 consumers interviewed, only 1,242 turned out to be buyers of SB and, therefore, the final sample is composed by 1,242 shoppers.

The telephone interview investigated: 1) socio-demographic characteristics and 2) the elements that characterize SB. Regarding the latter, the following factors were assessed: a) quality; b) sales promotional activities; c) price advantage; d) safety; e) level of innovation; f) environmental sustainability; g) link with the territory and tradition; h) ethics; i) assortment variety. They were measured by asking respondents to express a degree of agreement $/$ disagreement on a 5 -point scale $(1=$ completely disagree, $5=$ completely agree $)$ regarding the statements presented in Table 3 .

Women make up the majority of the sample $(81 \%)$; this is not surprising since they represent the main purchasing managers for Italian families. The average age is 50 with a range from 19 to 85 years. All members of the sample purchase SB products, mainly in hypermarkets or supermarkets. The main point of purchase format was stated at the beginning of the interview so that the consumer could be placed in one of the two groups analyzed. Therefore, the evaluation given on each distinctive SB factors was made with specific reference to the SB products acquired, in supermarket or hypermarket, and according to consumer group.

Statistical analyses were performed with SPSS 23.0 statistical analysis software (SPSS Inc, Chicago, IL).

\section{Results}

Before proceeding to the analysis of the differences found between the two shopper groups, key SB dimensions were analyzed independently from the point of sale format in order to draw up a ranking of the degree of importance allocated to each factor. Table 1 shows the average values and the relative standard deviations for each of the elements investigated. The data show that, in relation to the most important SB purchase factors, price ranks first, followed by promotion activities, safety, assortment variety and quality. This result seems to confirm the literature on the topic (Hoch \& Banerjy, 1993; Dhar \& Hoch, 1997; Rubio \& Yagüe, 2009; Lamey et al., 2012; Sethuraman \& Gielens, 2014).

The two groups (SB hypermarket shoppers and SB supermarket shoppers) are balanced by gender $\left(X^{2}(1)=0.121\right.$; $p>0.05)$, participant age $(t(1,240)=-1.132 ; p>0.05)$ and sample size $\left(X^{2}(1)=1,704 ; p>0,05\right)$. Furthermore, regarding other socio-demographic variables, no significant differences were found between the two groups of respondents. Specifically, this refers to the number of family members $\left(X^{2}(4)=6.410 ; p>0,05\right)$, the number of children and teenagers in the family $\left(X^{2}(4)=4.656 ; p>0.05\right)$, the educational level $\left(X^{2}(6)=1.959 ; p>0.05\right)$ and professional status $\left(X^{2}(6)=9.436 ; p>0.05\right)$. The composition of the two groups is shown in Table 2 .

Table 1. Means and Standard Deviations of SB purchase determinants

\begin{tabular}{lll}
\hline & Mean & Standard Deviation \\
\hline Price advantage & 3.676 & 1.033 \\
Sales promotional activities & 3.530 & 0.916 \\
Safety & 3.453 & 0.994 \\
Assortment variety & 3.412 & 0.966 \\
Quality & 3.390 & 0.873 \\
Link with the territory and tradition & 3.377 & 1.037 \\
Ethics & 3.296 & 1.021 \\
Innovation & 3.220 & 0.976 \\
Environmental sustainability & 3.130 & 1.043 \\
\hline
\end{tabular}

With reference to the first research question, that is, the existence of a difference in the evaluation of a SB between hypermarket and supermarket shoppers, the overall average evaluations made by the participants were compared, regardless of the type of factor investigated. The results of the t-test reveal the presence of a 
significant difference between the evaluations released by the two groups. Specifically, the opinion expressed by hypermarket shopper appears to be significantly higher than that issued by supermarket shopper $\left(M_{i p e r}=3.468\right.$, $\left.S E=0.028 ; M_{\text {super }}=3.328, \mathrm{SE}=0.029 ; t(1240)=3.448 ; p<0.05\right)$. Therefore, it can be stated that a hypermarket shopper's evaluation of a SB appears to be different than a supermarket shopper's.

Table 2. Groups composition

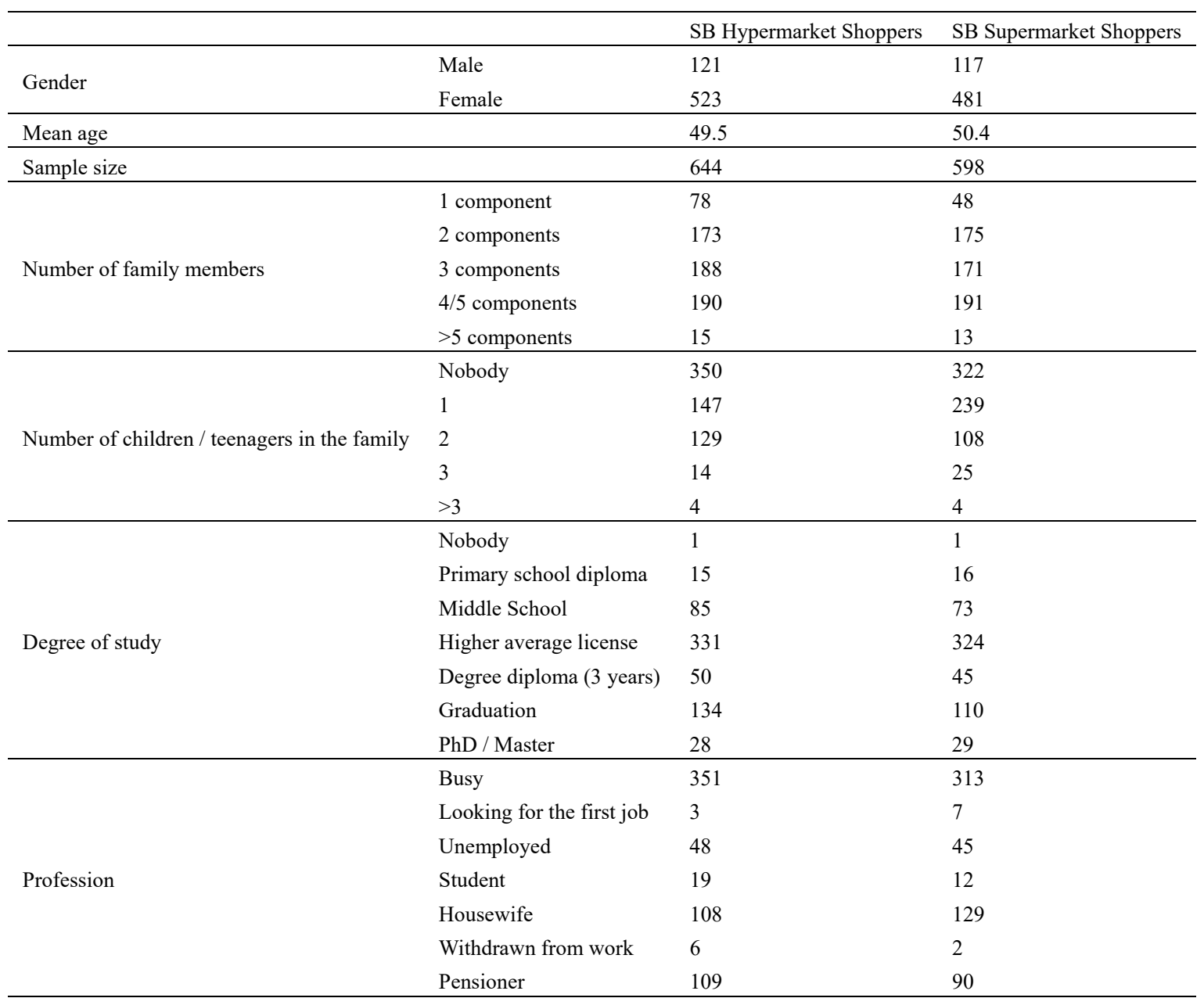

To respond to the second research question, the shoppers' opinions were analyzed in reference to the individual elements characterizing a SB. The first element investigated was the quality of the product. More specifically, the statements where the participants expressed their degree of agreement / disagreement were two: 1) I trust the quality of SB products; 2) SB products use good quality raw materials. With reference to both the quality of the products in general $\left(M_{\text {hyper }}=3.512, S E=0.038 ; M_{\text {super }}=3.383, S E=0.040\right)$, and the quality of the raw material $\left(M_{\text {hyper }}=3.405, S E=0.039 ; M_{\text {super }}=3.249, S E=0.040\right)$, the opinions expressed by hypermarket shoppers remain significantly higher than those of supermarket shoppers $(t(1240)=2,305 ; p<0.05 ; t(1240)=2.766 ; p<0.05)$.

On the contrary, the opinion expressed about sales promotional activities, regarding its frequency $\left(M_{\text {hyper }}=3.543\right.$, $\left.S E=0,042 ; \quad M_{\text {super }}=3.467, S E=0.043\right)$ and the advantage offered $\left(M_{\text {hyper }}=3.601, S E=0.040 ; M_{\text {super }}=3.503\right.$, $S E=0,041)$, does not differ between the two shopper groups $(t(1240)=1.278 ; p>0.05 ; t(1240)=1.703 ; p>0.05)$.

The opinion regarding SB price advantage is significantly different: shoppers who buy the SB in hypermarkets consider it to be more advantageous than those who buy it in supermarkets $\left(M_{\text {hyper }}=3.756, S E=0.040\right.$; $\left.M_{\text {super }}=3.590, S E=0.042 ; t(1240)=2.837 ; p<0.05\right)$. The same can be said for product safety; hypermarket shoppers give a higher rating $\left(M_{\text {hyper }}=3.557, \mathrm{SE}=0.039 ; M_{\text {super }}=3.341, S E=0.040 ; t(1240)=3.854 ; p<0.05\right)$. 
Table 3. Results

\begin{tabular}{|c|c|c|c|c|c|c|c|}
\hline \multirow[t]{2}{*}{ Variable } & \multirow[t]{2}{*}{ Item } & \multicolumn{2}{|c|}{$\begin{array}{l}\text { SB Hypermarket } \\
\text { Shopper }\end{array}$} & \multicolumn{2}{|c|}{$\begin{array}{l}\text { SB Supermarket } \\
\text { Shopper }\end{array}$} & \multicolumn{2}{|l|}{ TEST } \\
\hline & & Media & $S E$ & Media & $S E$ & T-test & Sign. \\
\hline Price advantage & SB products are very price convenient & 3.756 & 0.040 & 3.590 & 0.042 & 2.837 & $p<0.05$ \\
\hline $\begin{array}{l}\text { Sales promotional } \\
\text { activities }\end{array}$ & I often find SB products on offer & 3.543 & 0.042 & 3.467 & 0.043 & 1.278 & $\begin{array}{l}p= \\
0.201\end{array}$ \\
\hline Promotional activities & $\begin{array}{l}\text { The promotions offered on the SB are very } \\
\text { advantageous }\end{array}$ & 3.601 & 0.040 & 3.503 & 0.041 & 1.703 & $\begin{array}{l}p= \\
0.089\end{array}$ \\
\hline Safety & $\begin{array}{l}\text { SB products are carefully checked and } \\
\text { certified }\end{array}$ & 3.557 & 0.039 & 3.341 & 0.040 & 3.854 & $p<0.05$ \\
\hline Assortment variety & $\begin{array}{l}\text { SB products respond to different needs, they } \\
\text { are varied }\end{array}$ & 3.455 & 0.039 & 3.366 & 0.038 & 1.623 & $p=1.05$ \\
\hline Quality & I trust the quality of SB products & 3.512 & 0.038 & 3.383 & 0.040 & 2.305 & $p<0.05$ \\
\hline Quality & SB products use good quality raw materials & 3.405 & 0.039 & 3.249 & 0.040 & 2.766 & $p<0.05$ \\
\hline $\begin{array}{l}\text { Link with the territory } \\
\text { and tradition }\end{array}$ & $\begin{array}{l}\text { SB products are often linked to the territory } \\
\text { and to the Italian agri-food traditions }\end{array}$ & 3.463 & 0.039 & 3.284 & 0.044 & 3.041 & $p<0.05$ \\
\hline Ethics & $\begin{array}{l}\text { I trust the ethics of those who produce SB } \\
\text { products }\end{array}$ & 3.370 & 0.041 & 3.217 & 0.041 & 2.633 & $p<0.05$ \\
\hline Innovation & SB products offer innovative solutions & 3.292 & 0.039 & 3.144 & 0.039 & 2.683 & $p<0.05$ \\
\hline $\begin{array}{l}\text { Environmental } \\
\text { sustainability }\end{array}$ & SB products respect the environment & 3.192 & 0.042 & 3.063 & 0.041 & 2.185 & $p<0.05$ \\
\hline
\end{tabular}

The opinion expressed by the two groups is also significantly different in regards to secondary aspects that characterize the SB: the innovation level $\left(M_{\text {hyper }}=3.292, S E=0.039 ; M_{\text {super }}=3.144, S E=0.039 ; t(1239)=2.683\right.$; $p<0.05)$, environmental sustainability $\left(M_{\text {hyper }}=3.192, \mathrm{SE}=0.042 ; M_{\text {super }}=3.063, S E=0.041 ; t(1239)=2.185 ; p<0.05\right)$, its link with the territory and tradition $\left(M_{\text {hyper }}=3.463, S E=0.039 ; M_{\text {super }}=3.284, S E=0.044 ; t(1240)=3.041 ; p<0.05\right)$ and ethics $\left(M_{\text {hyper }}=3.370, S E=0.041 ; M_{\text {super }}=3.172, S E=0.041 ; t(1238)=2.633 ; p<0.05\right)$. However, significantly different judgments between the two shopper segments are not reported in regards to assortment variety $\left(M_{\text {hyper }}=3.455, S E=0.039 ; M_{\text {super }}=3.366, S E=0.038 ; t(1240)=1.623 ; p>0.05\right)$.

In summary, the sales promotional activities and the assortment variety of SB stand out as the only two dimensions for which hypermarket and supermarket shoppers do not express different judgments. The results can found in Table 3.

\section{Discussion}

The descriptive statistics show a ranking of purchase determinants that has price advantage in first place, followed by sales promotion activities, safety, assortment variety and product quality. The results obtained seem to confirm the predominance of the variable "price" as one of the main factors behind the decision to buy a SB product (Hoch \& Banerjy, 1993; Dhar \& Hoch, 1997; Rubio \& Yagüe, 2009; Lamey et al., 2012; Sethuraman \& Gielens, 2014), followed by sales promotion activities. However, the evidences collected also demonstrate how other factors distinguishing SBs have assumed importance, and in particular, the guarantee of a safe product, the assortment variety and the product quality. Lastly, in terms of importance, is environmental sustainability that, within the proposed comparative framework, does not seem to play a decisive role in the purchase decision. Innovation and ethics are also found at the bottom of the list.

Regarding the analysis of the differences between the two shopper segments, a significantly higher overall evaluation emerged for SB purchasing factors for hypermarket shoppers when compared to supermarket shoppers.

When the individual purchasing determinants are considered, the result of the research appears to be fairly well-defined. In fact, with the exception of the assortment variety and sales promotion activities, all additional elements characterizing a SB and are sued to justify its purchase, obtain significantly higher judgments from the hypermarket shoppers.

The difference between these two shopper profiles highlights relevant managerial implications, and also contributes to the academic debate on SBs and the determinants underlying their success in the market. In fact, the discovery that a consumer's perception of the SB can changing depending on the store format is quite 
significant. These differences can be seen from two prospective: supply and demand.

With reference to the offer, management policies of a SB and the related investments on the factors which characterize it might differ between formats. In fact, assortment policies, in terms of variety and in reference to the total number of SB products on the category level, can differ considerably between the different store formats ${ }^{7}$. The same can be said for pricing policies ${ }^{8}$ and for the articulation of the services offered. In fact, the average promotional pressure of hypermarkets is around $35 \%$ against $28 \%$ of supermarkets while, in relation to the breadth of assortment, the hypermarket counts 18,418 references versus the 10,459 of supermarkets (IRI Worldwide, 2016). Therefore, the management of retail mix levers could have a different impact on the consumer's perception; thus explaining the difference in opinion expressed by the two groups interviewed.

From the demand perspective, one must instead consider the different distribution formats. Indeed, those who buy SBs in hypermarket select the product from a large and vast assortment where there are numerous the purchase alternatives. Therefore, the decision to purchase a SB is deliberate, the result of a more conscious decision; the choice of one brand over another. On the other hand, for each product category, supermarket shoppers usually make their selection from a more limited number brands (variable according to category). As a result of this, the purchase of a SB may be "forced". Additionally, the significant differences found in consumer behavior in relation to their point of purchase, are also tied into the number of store visits. In fact, a supermarket is characterized by a higher visit frequency than a hypermarket and, simultaneously, by a lower average receipt total.

The aforementioned reasons may help explain what causes the difference in the opinions expressed by the two groups of shopper regarding the SB. It therefore would seem important, from both the point of view of the literature on the topic and from the managerial perspective, to examine these different inputs. Since the evaluations of the SB purchase determinants should be analyzed in relation to the channel in which SB was purchased, it follows that the communication policies should require an ad hoc formulation for each format considered. Hypermarkets, for example, could make better use of the available space at the point of sale for in-store communication. It could further exploit the layout and product display to better illustrate the distinctiveness of their SB products. In regard to the supermarkets, in parallel to the price advantage offered by $\mathrm{SB}$, a contextual evaluation of the other distinguishing factors should be considered. In fact, the results of this study highlight the need to continuously support a "narration" of a SB's distinctive factors through a communication process that is developed both inside and outside the point of sale. For specific factors, such as sustainability or innovation, the information should be conveyed with a wider variety of tools because, unlike price, whose reporting indicator appears to be immediately understood by the consumers, it is objectively more complicated to highlight the other elements of distinctiveness and worth.

\section{References}

Baltas, G. (1997). Determinants of store brand choice: A behavioral analysis. Journal of Product \& Brand Management, 6(5), 315-324. https://doi.org/10.1108/10610429710179480

Bettman, J. R. (1974). Relationship of information-processing attitude structures to private brand purchasing behavior. Journal of Applied Psychology, 59(1), 79-83. https://doi.org/10.1037/h0035817

Bodur, H. O., Tofighi, M., \& Grohmann, B. (2016). When Should Private Label Brands Endorse Ethical Attributes?. Journal of Retailing, 92(2), 204-217. https://doi.org/10.1016/j.jretai.2015.11.001

Brenner, M. S. (1994). Tracking New Products: A Practitioner's Guide. Research-Technology Management, 37(6), 36-40. https://doi.org/10.1080/08956308.1994.11671009

Caswell, J.A., \& Mojduszka, E.M. (1996). Using Informational Labeling to Influence the Market for Quality in Food Products. American Journal of Agricultural Economics, 78(5), 1248-1253. https://doi.org/10.2307/1243501

Chimhundu, R., Hamlin, R. P., \& Mcneill, L. (2010). Impact of Manufacturer Brand Innovation on Retailer Brands. International Journal of Business and Management, 5(9). https://doi.org/10.5539/ijbm.v5n9p10

Conn, C. (2005). Innovation in Private-Label Branding. Design Management Review, 16(2), 55-62. https://doi.org/10.1111/j.1948-7169.2005.tb00194.x

Cristini, G. (2012). Crisi dei consumi e marca commerciale: le opportunità di copacking per le PMI alimentari. Mercati e Competitività, 3, 57-83. https://doi.org/10.3280/MC2012-003004

Dhar, S. K., \& Hoch, S. J. (1997). Why Store Brand Penetration Varies by Retailer. Marketing Science, 16(3), 208-227. https://doi.org/10.1287/mksc.16.3.208 
Doyle, P., \& Bridgewater, S. (1998). Marketing and innovation. Innovation in Marketing, 1-16.

Egan-Wyer, C., Muhr, S. L., Pfeiffer, A., \& Svensson, P. (2014). The ethics of the brand. Ephemera: Theory and Politics in Organization, 14(1), 1-11.

Erdem, T., \& Chang, S. R. (2012). A cross-category and cross-country analysis of umbrella branding for national and store brands. Journal of the Academy of Marketing Science, 40(1), 86-101. https://doi.org/10.1007/s11747-011-0288-8

Esbjerg, L., Grunert, K. G., Bech-Larsen, T., Juhl, H. J., \& Brunsø, K. (2005). Manufacturer and retailer brands in food retail assortments. Notes from a shopping trip across Europe. MAPP Working Paper n. 85. University of Aarhus, Aarhus School of Business, The MAPP Centre. Retrieved from https://ideas.repec.org/p/hhb/aarmap/0085.html

Garretson, J. A., Fisher, D., \& Burton, S. (2002). Antecedents of private label attitude and national brand promotion attitude: similarities and differences. Journal of Retailing, 78(2), 91-99. https://doi.org/10.1016/S0022-4359(02)00071-4

Geyskens, I., Gielens, K., \& Gijsbrechts, E. (2010). Proliferating Private-Label Portfolios: How Introducing Economy and Premium Private Labels Influences Brand Choice. Journal of Marketing Research, 47(5), 791-807. https://doi.org/10.1509/jmkr.47.5.791

Gupta, R., \& Sen, S. (2013). The effect of evolving resource synergy beliefs on the intentions-behavior discrepancy in ethical consumption. Journal of Consumer Psychology, 23(1), 114-121. https://doi.org/10.1016/j.jcps.2012.07.004

Gupta, S., \& Kumar, V. (2013). Sustainability as corporate culture of a brand for superior performance. Journal of World Business, 48(3), 311-320. https://doi.org/10.1016/j.jwb.2012.07.015

Hardaker, G. (1998). An integrated approach towards product innovation in international manufacturing organisations. European Journal of Innovation Management, 1(2), 67-73. https://doi.org/10.1108/14601069810217248

Hoch, S.J., \& Banerji, S. (1993). When Do Private Labels Succeed? Sloan Management Review, 34(4). Retrieved from http://search.proquest.com/docview/1302972663/abstract/EFEAAFD769B1470EPQ/1

Klein, B., \& Leffler, K. B. (1981). The Role of Market Forces in Assuring Contractual Performance. Journal of Political Economy, 89(4), 615.

Kumar, N., \& Steenkamp, J. B. E. M. (2007). Brand versus Brand. International Commerce Review, 7(1), 46-53. https://doi.org/10.1007/s12146-007-0008-y

Lamey, L., Deleersnyder, B., Steenkamp, J. B. E., \& Dekimpe, M. G. (2012). The Effect of Business-Cycle Fluctuations on Private-Label Share: What Has Marketing Conduct Got to Do with It? Journal of Marketing, 76(1), 1-19. https://doi.org/10.1509/jm.09.0320

Lin, Y. C., \& Chang, C. A. (2012). Double Standard: The Role of Environmental Consciousness in Green Product Usage. Journal of Marketing, 76(5), 125-134. https://doi.org/10.1509/jm.11.0264

Lugli, G. (2009). Marketing distributivo. La creazione di valore nella distribuzione despecializzata. Utet Giuridica.

Rubio, N., \& Yagüe, M. J. (2009). The determinants of store brand market share. International Journal of Market Research, 51(4), 501-519.

Sethuraman, R., \& Gielens, K. (2014). Determinants of Store Brand Share. Journal of Retailing, 90(2), 141-153. https://doi.org/10.1016/j.jretai.2014.04.002

Ter Braak, A., Geyskens, I., \& Dekimpe, M. G. (2014). Taking private labels upmarket: Empirical generalizations on category drivers of premium private label introductions. Journal of Retailing, 90(2), 125-140. https://doi.org/10.1016/j.jretai.2014.01.003

Trijp, H. C. M. Van, Steenkamp, J. B. E. M., \& Candel, M. J. J. M. (1997). Quality Labeling as Instrument to Create Product Equity: The Case of IKB in the Netherlands. In Wierenga, B., van Tilburg, A., Grunert, K., Steenkamp, J. B. E. M., \& Wedel, M. (Eds.), Agricultural Marketing and Consumer Behavior in a Changing World, 201-215, Springer US. https://doi.org/10.1007/978-1-4615-6273-3_10

Veloutsou, C., Gioulistanis, E., \& Moutinho L. (2004). Own labels choice criteria and perceived characteristics in Greece and Scotland: factors influencing the willingness to buy. Journal of Product \& Brand 
Management, 13(4), 228-241. https://doi.org/10.1108/10610420410546943

Verbeke, W., \& Viaene, J. (1999). Beliefs, attitude and behaviour towards fresh meat consumption in Belgium: empirical evidence from a consumer survey. Food Quality and Preference, 10(6), 437-445. https://doi.org/10.1016/S0950-3293(99)00031-2

Verhoef, P. C., Nijssen, E.J., \& Sloot, L. M. (2002). Strategic reactions of national brand manufacturers towards private labels: An empirical study in The Netherlands. European Journal of Marketing, 36(11/12), 1309-1326. https://doi.org/10.1108/03090560210445191

Walsh, G., \& Mitchell, V. W. (2010). Consumers' intention to buy private label brands revisited. Journal of General Management, 35(3), 3-24.

\section{Notes}

Note 1. The most recent data provided by Nielsen at the continental level (2016) shows an average share of SB of about $30 \%$, with large differences between countries. For example, in the UK, the market share reached $46 \%$, while in the countries of new modernization such as Greece or Turkey the share is still comparatively more limited (respectively 22\% and 23\%). In Italy (Iri data), the SB share in 2016 stood at $18.5 \%$.

Note 2. Reference is made to the Annual Report on the distributor brand each year prepared by ADEM LAB of Parma University through the support of IRI Worldwide (2016).

Note 3. Corporate Social Responsibility refers to the scope of ethical implications within a strategic business vision. The objectives and nature of the CSR have been indicated by the European Commission in Communication no. 681 of 25 October 2015

Note 4. Reference should be made, among others, to the Social Report published each year by Sainsbury. In Italy we like to recall the social balance of Coop, Conad and Aspiag.

Note 5. These are the definitive categories from the GS1 model of category management "destination". They represent the categories that for their importance take on particular significance for consumers and distributors: in order to retain the demand, it is necessary in these cases to differentiate the range and be particularly appreciated for a distinctive offer.

Note 6. Reference is made to the Annual Report on the distributor brand each year prepared by ADEM LAB of Parma University through the support of IRI Worldwide (2016).

Note 7. In the Italian market, the SB assortment share (percentage of average number of references per point of sale) is $11.4 \%$ in hypermarkets and $13.5 \%$ in supermarkets (IRI Worldwide, 2016).

Note 8 . In the Italian market, SB's promotional pressure is $25.9 \%$ in hypermarkets and $19.7 \%$ in supermarkets (IRI Worldwide, 2016).

\section{Copyrights}

Copyright for this article is retained by the author(s), with first publication rights granted to the journal.

This is an open-access article distributed under the terms and conditions of the Creative Commons Attribution license (http://creativecommons.org/licenses/by/4.0/). 